УДК 340.1

DOI https://doi.org/10.32849/2663-5313/2021.4.32

\title{
Свгенія Павліченко,
}

канд. юрид. наук,

доцент кафедри кримінально-правових дисииплін

Криворізького факультету

Начіонального університету «Одеська юридична академія»

\section{Олег Стець,}

канд. юрид. наук, доиент,

завідувач кафедри конститучійного, міжнародного та приватного права

Криворізького факультету

Начіонального університету «Одеська юридична академія»

\section{Роман Шелудяков,}

канд. юрид. наук

доцент кафедри конституиійного, міжнародного та приватного права

Криворізького факультету

Національного університету «Одеська юридична академія»

\section{МЕТОДОЛОГІЧНІ ЗАСАДИ КОМПАРАТИВНОГО АНАЛІЗУ В СИСТЕМІ ЮРИДИЧНИХ ДОСЛІДЖЕНЬ}

У статті узагальнено наукові підходи до визначення сутності порівняльно-правового методу аналізу, визначено компаративістичні засади відомих методів наукового дослідження та обгрунтовано методологічні засади компаративістичного аналізу в системі юридичних досліджень.

У статті показано, що серед відомих видів методів наукового дослідження найважливіше значення належить компаративістичним дослідженням, в основу яких покладено метод порівняння. Особливо важливим є застосування даного методу в правовій науці.

Порівняння є основним логічним засобом пізнання об'єктивного світу. Порівняння є незмінним еле ментом усіх форм пізнання. Це безпосередньо стосується юридичної науки.

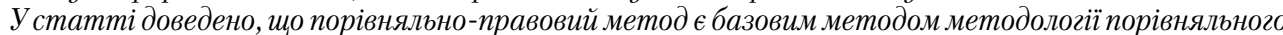
правознавства, що представлений єдністю способів дослідження й використовується для виявлення загальних та особливих ознак державно-правових явищ і встановлення закономірностей їх розвитку.

У статті відзначено, що порівняльно-правовий метод у методології юридичної науки $є$ одним з основних способів пізнання. Він передбачає порівняння процесів, явищ і понять юридичного характеру з метою вивчення їх подібності, виявлення причин розбіжностей. Порівняння дозволяє встановити, яким чином відбувався розвиток права і в якій послідовності.

Практична чінність порівняльного методу в правовій науиі полягає в тому, що він дозволяє знаходити оптимальні способи для вирішення сочіальних проблем. Він дозволяє зрозуміти, чому одна й та ж дія в правовій культурі однієї держави є правомірною, а іншої - злочинною.

У статті відзначено, що очінка компаративного правового елементу здійснюється в процесі аналітичної роботи й передбачає визначення системи правових об'єктів, що визначають самостійність компаративістичного значення.

Дослідження встановлено, що порівняльний метод у науковому сенсі може бути використаним під час співставлення характеристик двох або більше двох досліджуваних об'єктів з метою виявлення в них спільного й відмінного, формування класифікацій чи проведення типології. Об'єктами можуть виступати різні ідеї, результати досліджень, явища, процеси, якісні характеристики предметів тощо. Цей метод є загально емпіричним, дає підставу отримати теоретичні знання $і \epsilon$ загальноприйнятим методом наукових досліджень. Він є основою для багатьох прикладних досліджень, оскільки дозволяє на підставі характерних ознак об'єктів створювати їх групи. Найбільш поширеними видами порівняльних методів є наступні: історико-типологічне порівняння, що дозволяє виділити загальні ознаки в незв'язаних між собою явищах за однакових умов розвитку; історико-генетичне порівняння показує схожість між об'єктами, об'єднаними спільним походженням і умовами розвитку, та ӥх взаємовпливу.

Ключові слова: аналіз, метод, порівняння, порівняльно-правовий метод, компаративістика, юридичні дослідження. 
Постановка проблеми. Будь-які дослідження передбачать використання наукових методів. Науковий метод - це сукупність методів встановлення параметрів, структури, інших характеристик досліджуваних об’єктів.

Важливою стороною наукового методу, його невіддільною частиною для будь-якої науки є вимога об'єктивності, що виключає суб'єктивне тлумачення результатів. Не повинні прийматися на віру будь-які твердження, навіть якщо вони виходять від авторитетних учених.

Серед відомих видів методів наукового дослідження найважливіше значення належить компаративістичним дослідженням, в основу яких покладено метод порівняння. Особливо важливим є застосування даного методу в правовій науці, що підкреслює актуальність дослідження.

Метою статті є визначення сутності порівняння та обгрунтування методологічних засад компаративістичного аналізу в сис॥ темі юридичних досліджень.

Аналіз сучасних досліджень і публікацій. Кожний вид людської діяльності передбачає використання певних прийомів, способів, операцій з метою досягнення визначеної мети.

М.Г. Білуха зазначає, що сукупність цих прийомів визначається таким поняттям, як «метод», та вказує, що метод з грецької означає шлях пізнання [1]

3 точки зору A.M. Єріна, метод - це спосіб досягнення мети, розв'язання конкретної задачі; сукупність прийомів або операцій практичного впливу чи теоретичного освоєння об'єктивної дійсності з метою іiї пізнання [2].

O.В. Крушельницька дотримується думки, що методика дослідження - це система правил використання методів, прийомів та способів для проведення будь-якого дослідження. Дослідження передбачають використання наукових методів, де провідне місце належить порівняльним методам [3].

На думку О.В. Кустовської, порівняння це пізнавальна операція, що лежить в основі суджень про подібність або відмінність об'єктів. За допомогою порівняння виявляються якісні та кількісні характеристики предметів [4].

У Великій юридичній енциклопедії за редакцією О.В. Петришина відзначено, що порівняти - це зіставити одне з іншим з метою виявити їх співвідношення. Найпростіший і важливий тип відносин, що виявляються шляхом порівняння, - це відносини тотожності і відмінності [5].
На думку Г.С. Цехмістрової, порівняння - це той метод, за допомогою якого шляхом порівняння виявляється загальне і особливе в історичних та інших явищах, досягається пізнання різних ступенів розвитку одного і того ж явища або різних співіснуючих явищ [6].

Компаративісти схильні до розробки спеціальної теорії пізнання щодо правової компаративістики. Такої думки дотримується А.Х. Саідов. Вчений визначає ієрархічність методів компаративістики [7].

Ю.А. Тихоміров вказує на розмежування методів порівняння з іншими засадами наукового пізнання. На його думку, порівняльне правознавство має свою специфічну методологію [8].

М.Н. Марченко розглядає порівняльний метод як важливий атрибут порівняльного правознавства. Такий компаративістичний прийом пізнання, на думку вченого, може бути реалізованим для порівняльного пізнання різних правових сімей та національних правових систем [9].

В.А. Туманов вказує на доцільність застосування методичного інструментарію компаративістик[10].

Отже, більшість вчених дотримуються думки, що порівняння - це науковий метод пізнання, у прогресі якого невідоме, тобто досліджуване явище, предмети зіставляють із уже відомими, досліджуваними раніше для виявлення загальних ознак або відмінностей між ними.

Під час визначення методу правової компаративістики використовується порівняння щодо дослідження правового компаративного елемента.

Порівняння є основним логічним засобом пізнання об'єктивного світу. Порівняння $є$ незмінним елементом усіх форм пізнання. Це безпосередньо стосується юридичної науки.

Виклад основного матеріалу. Порівняльний метод у науковому дослідженні може бути використаним під час співставлення характеристик двох або більше двох досліджуваних об'єктів з метою виявлення в них спільного й відмінного, формування класифікацій чи здійснення типологізації. Об'єктами можуть виступати різні ідеї, результати досліджень, явища, процеси, якісні характеристики предметів тощо. Цей метод $є$ загальноемпіричним, дає підставу отримати теоретичні знання і $є$ загальноприйнятим методом наукових досліджень. Він $є$ основою для багатьох прикладних досліджень, оскільки дозволяє на підставі характерних ознак об'єктів створювати їх групи. Найбільш поширеними видами порів- 
няльних методів є наступні: історико-типологічне порівняння, що дозволяє виділити загальні ознаки в незв'язаних між собою явищах за однакових умов розвитку; історикогенетичне порівняння показує схожість між об'єктами, об'єднаними спільним походженням і умовами розвитку, та їх взаємовпливу.

Порівняльно-правовий метод є базовим методом методології порівняльного правознавства, що представлений єдністю способів дослідження й використовується для виявлення загальних та особливих ознак державно-правових явищ і встановлення закономірностей їх розвитку.

Відомо, що розвиток теорії порівняльноправового методу почався в 60 -х роках 20 століття. На початковому етапі становлення порівняльно-правового методу відбувалося в рамках широкомасштабної проблеми, а саме системи методів, що застосовуються правознавством. Таким шляхом були сформульовані фундаментальні положення, що характеризують порівняльно-правовий метод.

Завдяки розробці теорії порівняльноправового методу в рамках юридичної компаративістики, який потім активно став застосовуватися іншими теоретичними юридичними науками, компаративістику називають методологічною юридичною наукою. Порівняльно-правовий метод грунтується на порівнянні пізнавальної діяльності.

Слід мати на увазі, що будь-яке наукове порівняння має три основні прояви:- логічний прийом пізнання; процес, або особлива форма пізнавальної діяльності; особливий пізнавальний результат.

У структурі наукового порівняння виділяються наступні елементи: об'єкт, який порівнюється;·об'єкт з яким порівнюють; властивості, за якими порівнюються об'єкти; юридична оцінка, висновки, зроблені на підставі порівняння.

Щодо використання порівняльно-правового методу в юридичній науці можна зазначити, що він завжди займав значне місце незалежно від того, як його розуміли. Становлення та розвиток юридичної науки з самого початку було пов'язане 3 використанням порівняльно-правового методу. Порівняльно-правовий метод не є самоціллю. Він служить певній пізнавальній задачі, як і спеціально-наукові методи правової науки.

Порівняльно-правовий метод є багатофункціональним, тобто він може бути використаний і на теоретичному, і на емпіричному рівні пізнання Для нього характерним $є$ оціночний підхід.

Порівняльно-правовий метод $€$ необхідним, але аж ніяк не єдиним елементом методологічного апарату порівняльного правознавства. Жоден з методів на практиці не діє в чистому вигляді, він завжди взаємозалежний з іншими методами. Порівняння як таке не може розглядатися у відриві від інших логічних прийомів пізнання (аналізу, синтезу, індукції, дедукції, узагальнення). Окремо один від одного ці компоненти загальної системи дослідницьких засобів існують лише як уявна абстракція. Таким чином, можна виділити порівняння і розглядати його окремо від інших логічних прийомів, але у загальному процесі мислення воно перебуває в нерозривному зв'язку та взаємодії з усіма іншими прийомами пізнання.

Порівняльно-правовий метод у методології юридичної науки є одним з основних способів пізнання. Він передбачає порівняння процесів, явищ і понять юридичного характеру з метою вивчення їх подібності, виявлення причин розбіжностей. Порівняння дозволяє встановити, яким чином відбувався розвиток права і в якій послідовності.

Завдяки порівняльному методу з'явилася нова наукова галузь - порівняльне правознавство, що займається вивченням і порівнянням різних правових систем світових держав. Під час вивчення зарубіжного досвіду правознавства держава може вдосконалювати власну юридичну систему, відмовлятися від застарілих недосконалих методів, використовувати позитивний досвід у розвитку свого законодавства.

Практична цінність порівняльного методу в правовій науці полягає в тому, що він дозволяе знаходити оптимальні способи для вирішення соціальних проблем. Він дозволяє зрозуміти, чому одна й та ж дія в правовій культурі однієї держави є правомірною, а іншої - злочинною. Методи порівняльного підходу включають різні способи порівняння:

- функціональний, що дозволяє зіставляти функції, які виконує той чи інший інститут держави;

- нормативний, що використовує терміни і категорії специфічних правових систем $з$ метою аналізу норм права та законодавчих рішень;

- проблемний, який порівнює вирішення певних правових розбіжностей у рамках законодавчої системи та аналізує можливість застосування цих рішень у рамках свого законодавства;

- текстуальний, який аналізує, яке текстове оформлення найбільш продуктивно впливає на реалізацію правових норм у національному масштабі.

Порівняльне правознавство розглядається в спеціалізованій літературі в трьох 
основних аспектах: як порівняльний метод дослідження; як галузь самостійної науки; як поєднання методу і окремої наукової дисципліни.

Більш сучасним вважається третій підхід, оскільки він визнає, що порівняльне правознавство може бути окремим методом всієї юридичної науки, який дозволяє вивчати перелічені питання, а також може бути самостійною наукою, оскільки має свій предмет дослідження, сферу застосування та практичне значення.

Як і будь-який науковий спосіб пізнання, методи порівняльного підходу реалізуються завдяки дотриманню основних принципів:

- порівняння правових норм, що регулює функціональну сторону правових рішень, тобто те, як вони вирішують потенційні соціальні проблеми;

- урахування умов історичного часу розвитку правової норми, її соціальної зумовленості;

- критичного розгляду отриманих даних.

Застосування методу в правознавстві дозволяє виявляти оптимальні способи вирішення правових питань.

Порівняння виступає загальною настановкою пізнання.

Отже, у системі порівняльного правознавства застосовується широке коло методів, особливістю яких є застосування порівняльного методу аналізу. Специфічною особливістю вказаного методу є як застосування прийомів аналізу й синтезу, індукції й дедукції, так і аналогії щодо існуючих явищ. Саме тому зазначений метод можна вважати переважаючим.

Порівняння слід розглядати як пізнавальну операцію, сутність якої зводиться до виявлення подібного й різного щодо правових об'єктів досліджень. В основі дослідження мають бути напрями класифікації та оцінка правових об'єктів різного спрямування.

Слід вказати, що оцінку правових компонентів треба пов'язувати із процесом класифікації, що визначає порівняльно-правову діяльність із компаративним правовим об'єктом. Це означає, що особливістю функціонально-правового компоненту в умовах правового середовища залишається суб'єкт пізнавальної діяльності.

Оцінка компаративного правового елементу здійснюється в процесі аналітичної роботи й передбачає визначення системи правових об'єктів, що визначають самостійність компаративістичного значення.

Компаративістичні прийоми пізнання формують оціночні показники юридичної діяльності та дають підставу визначити сутність правових процесів.

За результатами проведення порівняльного аналізу визначаються кількісні показники як правових норм, так і правових систем. Також у процесі порівняльноправового аналізу можна визначити відмінності внутрішнього змісту навіть у рамках однієї правової системи та у порівнянні з існуючими.

Компаративістичний метод аналізу як основний прийом пізнання юридичних наук визначився як правовий внаслідок визначення порівняльного правознавства як самостійного напряму наукових досліджень.

Основною задачею порівняльного правознавства $€$ визначення можливості поєднання існуючих прийомів пізнання із методами порівняння та здійснення спеціального аналізу компаративістичного характеру.

Порівняльний метод аналізу треба розглядати як практичний інструмент щодо удосконалення наукових досліджень в сфері права.

Метод порівняння містить у собі більш широкий спектр типових рішень, ніж замкнута правова наука. Порівняльний метод визначає природу правової дійсності.

Він залишається основою для оцінки отриманих результатів компаративістичного дослідження й може розглядатись як основа методологічних засад цього дослідження.

\section{Висновки}

На підставі проведених досліджень можна зробити висновки, що порівняльний метод дозволив виділитися окремій науковій галузі - порівняльного правознавства, що займається вивченням і порівнянням різних правових систем світових держав. Подальші дослідження передбачають вивчення існуючих видів порівняльно-правового методу та вибір найдоцільнішого 3 науково-практичного погляду під час дослідження правових систем.

\section{Список використаних джерел:}

1. Білуха М.Г. Основи наукових досліджень: Підручник для студ. екон. спец. вузів / М.Г. Білуха. Київ : Вища школа. 3-тє вид 2017. 271 с.

2. Єріна А.М. Методологія наукових досліджень: Навчальний посібник. Київ, 2004. 212 с.

3. Крушельницька О.В. Методологія та організація наукових досліджень : Навч. посібник / О.В. Крушельницька. Київ : Кондор, 2003. 192 с.

4. Кустовська О.В. Методологія системного підходу та наукових досліджень : курс лекцій. Тернопіль : Економічна думка, 2005. 124 с.

5. Методика проведення порівняльно-правових досліджень. Велика українська юридична 
енциклопедія : у 2 т : Загальна теорія права, 2017. 952 с. / О.В. Петришин (відп. ред.) та ін.

6. Основи наукових досліджень : навчальний посібник. Цехмістрова Г.С. Київ : Видавничий Дім «Слово», 2003. 240 с.

7. Саидов А.Х. Сравнительное правоведение (основные правовые системы современности) : учебник / Под ред. В.А. Туманова. Москва : Юристъ, 2003. 448 с.
8. Тихомиров Ю.А. Административное право и процесс: полный курс. Москва : Издательство HOPMA, 2005. 698 c

9. Марченко, М.Н. Государство и право в условиях глобализации / М.Н. Марченко. Москва : Проспект, 2013. 400 c.

10. Саидов А.Х., Туманов В.А. (Ред.) Сравнительное правоведение: учебник. Москва : Юрист, 2003. $448 \mathrm{c}$.

Yevheniia Pavlichenko, Oleh Stets, Roman Sheludiakov. Methodological fundamentals of comparative analysis in the system of legal research

The article shows the essence of the comparative law research method as one of the specific ways of applying general scientific methods to the study of legal phenomena. It has been established that the comparative law method is the one that is most often interpreted in the legal science. It has been shown that a close relationship exists between the individual branches of the law based on the interaction and the mutual assistance between various methods of studying thereof.

It has been shown that, when studying legal phenomena, all comparative law method's strong points can be implemented only if its application is strictly systemic and purposeful. With all the variety of its possible particular manifestations, the research method as a whole must act as internally coherent and consistent in all its parts, and constitute a harmonious hierarchy of various levels of legal research.

It has been established that conducting research in the field of comparative jurisprudence involves the use of a wide range of both general scientific and special methods. The main emphasis is laid on the comparative law method that can act, among other things, as a subject of research and, at the same time, it can be used in a wide variety of aspects. It has been shown that the comparative law method is the most instrumental in revealing common features and identifying specific characteristics inherent in various countries or different time periods.

It has been proved that the comparative method is an integral part of the methodology of comparative studies applied in the legal sciences. This method acquired great importance at the beginning of the last century, when comparative legal research in the private law sphere became more active, while the needs of the trade practice determined trends towards the unification and the harmonization of national legislations. As a result, not only concrete comparative studies, but also the methodology of comparative jurisprudence developed in a new qualitative way.

The article proves that the comparative legal method is the basic method of the methodology of comparative jurisprudence, which is represented by the unity of research methods and is used to identify general and special features of state and legal phenomena and establish patterns of their development.

The article notes that the comparative legal method in the methodology of legal science is one of the main ways of cognition. It involves comparing processes, phenomena and concepts of a legal nature in order to study their similarities, identify the causes of differences. The comparison allows us to establish how the development of law, in what sequence it happened.

Key words: methodology, comparative law research, structuralism, analytical method, historical method, contextual law approach, comparison levels. 